\title{
Clinical evaluation of domestic dental whitening strategies
}

\author{
Avaliação clínica de estratégias de clareamento dental doméstico \\ Evaluación clínica de estratégias de blanqueamiento dental doméstico
}

Received: 04/11/2021 | Reviewed: 04/19/2021 | Accept: 04/24/2021 | Published: 05/09/2021

\author{
João Victor Batista Soares Silva \\ ORCID: https://orcid.org/0000-0002-2834-0846 \\ Universidade Federal de Pernambuco, Brazil \\ E-mail: joaosoares.09@hotmail.com \\ Vitória Alves de Melo \\ ORCID: https://orcid.org/0000-0002-1667-6609 \\ Universidade Federal de Pernambuco, Brazil \\ E-mail: vitorialvesm@gmail.com \\ Marlon Ferreira Dias \\ ORCID: https://orcid.org/0000-0001-7837-3024 \\ Universidade Federal de Pernambuco, Brazi \\ E-mail: marlondias03@gmail.com \\ Paulo Cardoso Lins-Filho \\ ORCID: https://orcid.org/0000-0002-1809-7168 \\ Universidade Federal de Pernambuco, Brazil \\ E-mail: paulocardoso09@hotmail.com \\ Fábio Barbosa de Souza \\ ORCID: https://orcid.org/0000-0003-2841-9543 \\ Universidade Federal de Pernambuco, Brazil \\ E-mail: fabio.souza@ufpe.br \\ Renata Pedrosa Guimarães \\ ORCID: https://orcid.org/0000-0003-3504-8998 \\ Universidade Federal de Pernambuco, Brazil \\ E-mail: renata.guimaraes@ufpe.br
}

\begin{abstract}
Tooth bleaching has become the first clinical option in reversing chromatic changes. This study evaluated the efficiency of four different approaches for home-based chemically induced tooth whitening. 32 patients were randomly distributed into four groups $(\mathrm{n}=8)$, according to the bleaching technique performed: $\mathrm{G} 1$ : control group - athome dental bleaching with $10 \%$ carbamide peroxide (Whiteness Perfect/FGM) delivered in a customized tray, G2: teeth whitening pen containing hydrogen peroxide (Walgreens), G3: night-time whitening gel (CVS) containing hydrogen peroxide and G4: whitening strips (3D White Oral B) containing 10\% hydrogen peroxide. Chromatic changes $(\Delta \mathrm{E})$ were collected at baseline and at the middle and end of the treatment, using a digital spectrophotometer (EasyShade - Vita). Tooth sensitivity, gingival irritation, and degree of satisfaction were also recorded. The comparison between the average $\Delta \mathrm{E}$ means, considering the final and initial values, revealed a statistically significant difference between the results obtained by G1 $(\Delta \mathrm{E} 2=11.65)$ and the other groups $(\Delta \mathrm{E} 2$ of $\mathrm{G} 2=4.38, \mathrm{G} 3=4.83$ and $\mathrm{G} 4$ $=8.32$ ). No significant difference was observed in the occurrence of tooth sensitivity and gingival irritation. The patients from G1 and G4 were more satisfied with the treatment outcome.
\end{abstract}

Keywords: Esthetics; Tooth bleaching; Clinical trial; Peroxides.

\section{Resumo}

O clareamento dental tornou-se a primeira opção clínica na reversão das alterações cromáticas. Este estudo avaliou a eficiência de quatro abordagens diferentes para o clareamento dentário induzido quimicamente em casa. 32 pacientes foram distribuídos aleatoriamente em quatro grupos $(\mathrm{n}=8)$, de acordo com a técnica de clareamento realizada: $\mathrm{G} 1$ : grupo controle - clareamento convencional supervisionado com peróxido de carbamida $10 \%$ (Whiteness Perfect / FGM) aplicado em moldeira customizada, G2: caneta clareadora dentária contendo peróxido de hidrogênio (Walgreens), G3: gel clareador noturno (CVS) contendo peróxido de hidrogênio e G4: tiras clareadoras (3D White Oral B) contendo $10 \%$ de peróxido de hidrogênio. As alterações cromáticas $(\Delta \mathrm{E})$ foram coletadas no início e no meio e no final do tratamento, por meio de espectrofotômetro digital (EasyShade - Vita). Sensibilidade dentária, irritação gengival e grau de satisfação também foram registrados. A comparação entre as médias do $\Delta \mathrm{E}$ médio, considerando os valores final e inicial, revelou diferença estatisticamente significativa entre os resultados obtidos pelo $\mathrm{G} 1(\Delta \mathrm{E} 2=$ $11,65)$ e os demais grupos ( $\Delta \mathrm{E} 2$ do $\mathrm{G} 2=4,38, \mathrm{G} 3=4,83$ e G4 $=8,32)$. Não foi observada diferença significativa na ocorrência de sensibilidade dentária e irritação gengival. Os pacientes do G1 e G4 ficaram mais satisfeitos com o resultado do tratamento. 
Palavras-chave: Estética; Clareamento dentário; Ensaio clínico; Peróxidos.

\section{Resumen}

El blanqueamiento dental se ha convertido en la primera opción clínica para revertir los cambios cromáticos. Este estudio evaluó la eficiencia de cuatro enfoques diferentes para el blanqueamiento dental inducido químicamente en el hogar. 32 pacientes fueron distribuidos aleatoriamente en cuatro grupos $(n=8)$, según la técnica de blanqueamiento realizada: G1: grupo control - blanqueamiento convencional supervisado con peróxido de carbamida al $10 \%$ (Whiteness Perfect / FGM) entregado en bandeja personalizada, G2: lápiz blanqueador de dientes que contiene peróxido de hidrógeno (Walgreens), G3: gel blanqueador nocturno (CVS) que contiene peróxido de hidrógeno y G4: tiras blanqueadoras (3D White Oral B) que contienen peróxido de hidrógeno al $10 \%$. Los cambios cromáticos $(\Delta \mathrm{E})$ se recogieron al inicio del estudio y en la mitad y al final del tratamiento, utilizando un espectrofotómetro digital (EasyShade - Vita). También se registraron la sensibilidad dental, la irritación gingival y el grado de satisfacción. La comparación entre las medias $\Delta \mathrm{E}$ promedio, considerando los valores final e inicial, reveló una diferencia estadísticamente significativa entre los resultados obtenidos por G1 $(\Delta \mathrm{E} 2=11.65)$ y los demás grupos $(\Delta \mathrm{E} 2$ de $\mathrm{G} 2=$ $4.38, \mathrm{G} 3=4.83$ y G4 $=8.32$ ). No se observaron diferencias significativas en la aparición de sensibilidad dental e irritación gingival. Los pacientes de G1 y G4 estaban más satisfechos con el resultado del tratamiento.

Palabras clave: Estética; Blaqueamiento dental; Ensayo clínico; Peróxidos.

\section{Introduction}

Disharmony in the shape and color of the teeth directly interferes with the attractiveness of the smile, which may have consequences for the individual's personal life, psychological profile, and even professional attitude, which can cause significant negative effects on health and well-being (Afroz et al., 2016).

Tooth bleaching has become the first option in reversing chromatic changes in teeth and can have a positive effect depending on the etiology and intensity of tooth darkening. Several techniques are available, combined with whitening performed in the office with hydrogen peroxide at a concentration of $35-37 \%$ and supervised whitening, where the patient, under the supervision of the dentist, uses carbamide peroxide in a concentration ranging from 10 to $22 \%$ at home (Epple; Meyer; Enax, 2019; Fiorillo et al., 2019).

The bleaching agents act mainly through the oxidation of organic compounds. These agents are highly unstable and, when in contact with the tissue, release free radicals (mainly nascent oxygen) that oxidize the pigments. The released oxygen penetrates the dentinal tubules and acts on compounds with carbon rings that are highly pigmented, converting them into lighter compounds (Carey, 2014). The success of whitening will depend directly on the concentration of the agent, its ability to penetrate to reach the chromophoric molecules, and the duration and number of times that it remains in contact with these molecules (Wang et al., 2020).

The most frequently recommended treatment is at-home bleaching however, some patients are still uncomfortable about wearing a bleaching tray for longer periods of time (Cordeiro et al., 2019). In addition to the techniques performed under the supervision of the dentist, domestic whiteners, called over-the-counter products, are also available directly from pharmacies and supermarkets, without the need for professional monitoring. This whitening modality has been increasingly encouraged and motivated by patients desire to obtain "white" teeth (Demarco; Meireles; Masotti, 2009).

Many studies have evaluated bleaching effectiveness using these domestic methods (Pinto et al., 2017; Li et al., 2003; Carlos et al., 2016), however, only a few6 observed tooth sensitivity, and gingival irritation between different delivery methods of peroxide hydrogen, which makes the present study of great value for the scientific community and the consumer population.

Therefore, this study aimed to evaluate tooth sensitivity, gingival irritation, and satisfaction degree of young patients submitted to a conventional tray-delivered system in comparison with bleaching strips or prefilled disposable trays.

\section{Methodology}

This study was submitted and approved by Human Research Ethics Committee of Federal University of Pernambuco 
(Protocol number 54637316.0.0000.5208). All provisions of the Declaration of Helsinki were followed along with the Consolidated Standards of Reporting Trials statement.

This clinical trial was performed with patients who was looking for whitening treatment at Dentistry graduation course clinics. All volunteers agreed to participate in the present research and signed a consent form to take part in the study.

The dependent variables were: 1. Speed and Efficacy of the whitening effect; 2. Occurrence of gingival changes; 3. Tooth sensitivity; 4. Degree of patient satisfaction with treatment outcome.

\section{Study Design}

This was a single-blind, controlled, and parallel randomized clinical trial in which the evaluator was blinded to the group assignment.

\section{Eligibility Criteria}

Thirty-two patients were selected, of both genders, over 18 years old, to be eligible to the study they had to present natural anterior teeth, pulp vitality, naturally or physiologically darkened, with absence of restorations involving the buccal face, tooth shade A3 or darker on the VITA scale and with satisfactory oral health. Patients with tooth sensitivity, cervical injuries, or fractures, pregnant or lactating women, smokers, children, and teenagers (age up to 18 years), caries or periodontal disease, history of cancerous lesions, prostheses and/or previous restorations on anterior teeth were excluded.

After physical examination and anamnesis, patients received guidance about oral hygiene and aspects related to whitening treatment, such as: mechanism of action, adverse reactions, trans precautions and post treatment. During the period of this study, all patients were asked to use conventional white toothpaste and a soft bristle brush.

\section{Randomization and Allocation Concealment}

The individuals were randomly assigned into four groups $(n=8)$, through the opaque envelope randomization technique, according to the whitening technique performed. Group 1 (G1): At-home bleaching with 10\% carbamide peroxide; Group 2 (G2): Teeth whitening pen; Group 3 (G3): Whitening agent in brush-on gel; and Group 4 (G4): Domestic whitening with whitening strips.

\section{Study Intervention}

The bleaching treatment was conducted according to the following protocol:

1ST SESSION: 1. Consent Form read and signed; 2. Anamnesis; 3. Physical examination; 4. Clinical chart fill-out; 5. Prophylaxis with pumice paste and water; 6. Photographic registry; 7. Initial color registration; 8. Product delivery 9. Directions for use, based on the guidelines recommended by the manufacturers for each delivery system.

SUBSEQUENT SESSIONS: 1. Physical examination; 2. Assessment of intraoperative sensitivity; 3. Prophylaxis with pumice paste and water; 4. Photographic record; 5. Color registration, 6. Guidelines for oral hygiene.

For G1 (positive control), at-home dental bleaching technique was performed. In the first clinical session, in addition to the procedures already described, upper and lower impressions were taken with alginate (Jeltrate, Dentsply, York, PA, EUA) to prepare dental stone models used in a custom acetate tray preparation, fabricated in a vacuum forming machine with the aid of a vacuum plasticizer (Plastivasc P7, Bioart, São Carlos, SP, BRA). In the next clinical session, the individualized tray was delivered with the bleaching agent (10\% carbamide peroxide, Whiteness Perfect, FGM, Joinville, SC, BRA). Guidance was given regarding the use and care during treatment, which consisted of using the tray for 08 hours daily, while sleeping, for 15 days. The other procedures followed the general protocol. 
For G2, G3, and G4, domestic bleaching techniques were performed. In the first clinical session, in addition to the procedures described above, only upper alginate impressions (Jeltrate, Dentsply) were performed. After disinfection, these impressions were filled with dental stone (Diamante, IGE, Araripina, PE, BRA). A 0.9-mm soft vinyl material (Whiteness, FGM, Joinville, SC, BRA) was used to fabricate a customized tray in a vacuum forming machine (Plastivasc P7, Bioart), which was used as a guide to standardize the color measurements subsequently performed.

For G2, a whitening pen solution containing hydrogen peroxide, which concentration was not reported by the manufacturer (Teeth Whitening Pen, Walgreens, Chicago, IL, EUA) was delivered, according to the usage guidelines described by the manufacturer. It was recommended to apply a layer of gel on the surface of the teeth and let it dry for 30 seconds, use three times a day, and avoid eating, drinking, or smoking for 30 minutes after application. The whitening pen was used for 15 consecutive days.

For G3, patients received a brush-on gel containing hydrogen peroxide, which concentration was not reported by the manufacturer (Nighttime Whitening Gel - CVS, Woonsocket, RI, EUA). This dental bleaching system was used according to the manufacturer's instructions. It was recommended to apply a thin layer of gel to each tooth and then brush the teeth with soft movements, preferable before going to sleeping. The product was used once a day for 14 days.

For G4, patients received a kit of disposable whitening strips (OralB Whitestrips, P\&G, Oral B, EUA), containing $10 \%$ hydrogen peroxide solution, and used them according to the guidelines described by the manufacturer. It was recommended that the patient handle the strips with clean and dry hands, the package contained two types of strips, smaller for the lower teeth and larger for the upper teeth. The patient applied mild pressure on the teeth, ensuring good contact. The strips were used for 30 minutes, twice a day, for seven days.

\section{Color evaluation}

Chromatic modification readings were performed at baseline (before the beginning of the study for the four groups), at the middle of the treatment (for G1, G2, and G3, seven days after baseline; for G4 four days after baseline), and at the end of the treatment (for G1, G2 and G3 15 days after baseline; for G4 seven days after baseline). Measurements were performed with a digital spectrophotometer (EasyShade, Vita, Bad Säckingen, Germany). For each tooth to be evaluated, a window whose diameter corresponds to the diameter of the Spectrophotometer tip was created on the buccal surface of the customized tray guide. This way, the measurement was always taken at the same location, after tooth prophylaxis with pumice and water. The shade of the middle third of the upper central incisors was taken as reference. The arithmetic means between the values of $\mathrm{L} *$ $\mathrm{a} *$ and $\mathrm{b} *(\mathrm{~L} *$ indicates luminosity, $\mathrm{a} *$ represents color and saturation on the red-green axis, and $\mathrm{b} *$ means color and saturation on the yellow-blue axis) of these teeth were considered.

To determine color differences at different times of treatment, $\Delta \mathrm{E}$ was calculated using the formula: $\Delta \mathrm{E} *=[\Delta \mathrm{L} * 2+$ $\Delta \mathrm{a} * 2+\Delta \mathrm{b} * 2] 1 / 2$, where $\Delta \mathrm{L} *=\mathrm{L} 0-\mathrm{L} 1 ; \Delta \mathrm{a}=\mathrm{a} 0-\mathrm{a} 1 ; \Delta \mathrm{b}=\mathrm{b} 0-\mathrm{b} 1$. The $\Delta \mathrm{E}$ were checked at two different times: $\Delta \mathrm{E} 1:$ Color registered in the middle of the treatment by color at baseline; $\Delta \mathrm{E} 2$ : Color at the end of the treatment by color at baseline.

\section{Evaluation of tooth sensitivity and gingival irritation}

In the initial clinical examination, a sensitivity test was carried out. The patients manifested spontaneously in response to the application of an air jet in the cervical region of the buccal surface of the bleached teeth. Evaluation of the presence of gingival irritation through clinical analysis of signs of inflammation, such as alteration of the gingival contour, volume, and surface texture were performed.

Besides the analysis of treatment efficiency, patients were asked about the occurrence of tooth sensitivity during and immediately after the use of whitening agents. The sensitivity was measured using a visual analog scale (VAS) (Huskisson; 
Jones; Scott, 1976). At the end of the treatment, the patients were evaluated for their degree of satisfaction with treatment outcome, by filling out a structured form.

\section{Statistical Analysis}

The data was analyzed descriptively and inferentially, and statistical calculations were performed using the IBM SPSS version 23 program. The descriptive analysis was through absolute frequencies and percentages for categorical variables and measures, means, standard deviation, median, and percentiles for numerical variables. Inferential analysis was performed using paired t-Student statistical tests (in comparison between the evaluations) and in the comparison between the groups the $\mathrm{F}$ test (ANOVA) was performed for the numerical variables and Fisher's Exact test for categorical variables. The margin of error adopted in the decision of the statistical tests was $5 \%$ and a confidence interval of $95 \%$. Fisher's exact test was used due to the absence of the condition to use Pearson's chi-square test. The verification of the normality of the data was performed using the Kolmogorov-Smirnov test.

\section{Results}

The sample was composed by $53.1 \%$ women with an average age of 24.03 years, ranging from 19 to 37 years old. Regarding education level, $75 \%$ had incomplete higher education; $12.5 \%$ complete higher education and $12.5 \%$ complete secondary education. Regarding marital status, $93.7 \%$ of patients were single and $6.3 \%$ were married.

Regarding the value of $\mathrm{L} *$, significant variations were observed in G1 and G4, an increase in this value was observed at after the bleaching treatment, there was, however, for G2 and G3, a decrease in the value of $\mathrm{L} *$, presenting a negative average between the final and initial evaluation (Table 1). Posttreatment tooth shades were darker in G2 and G3 (Table 2).

Table 1 - Statistics for the variables "mean of L", "mean of a" and "mean of b "according to the group and assessment.

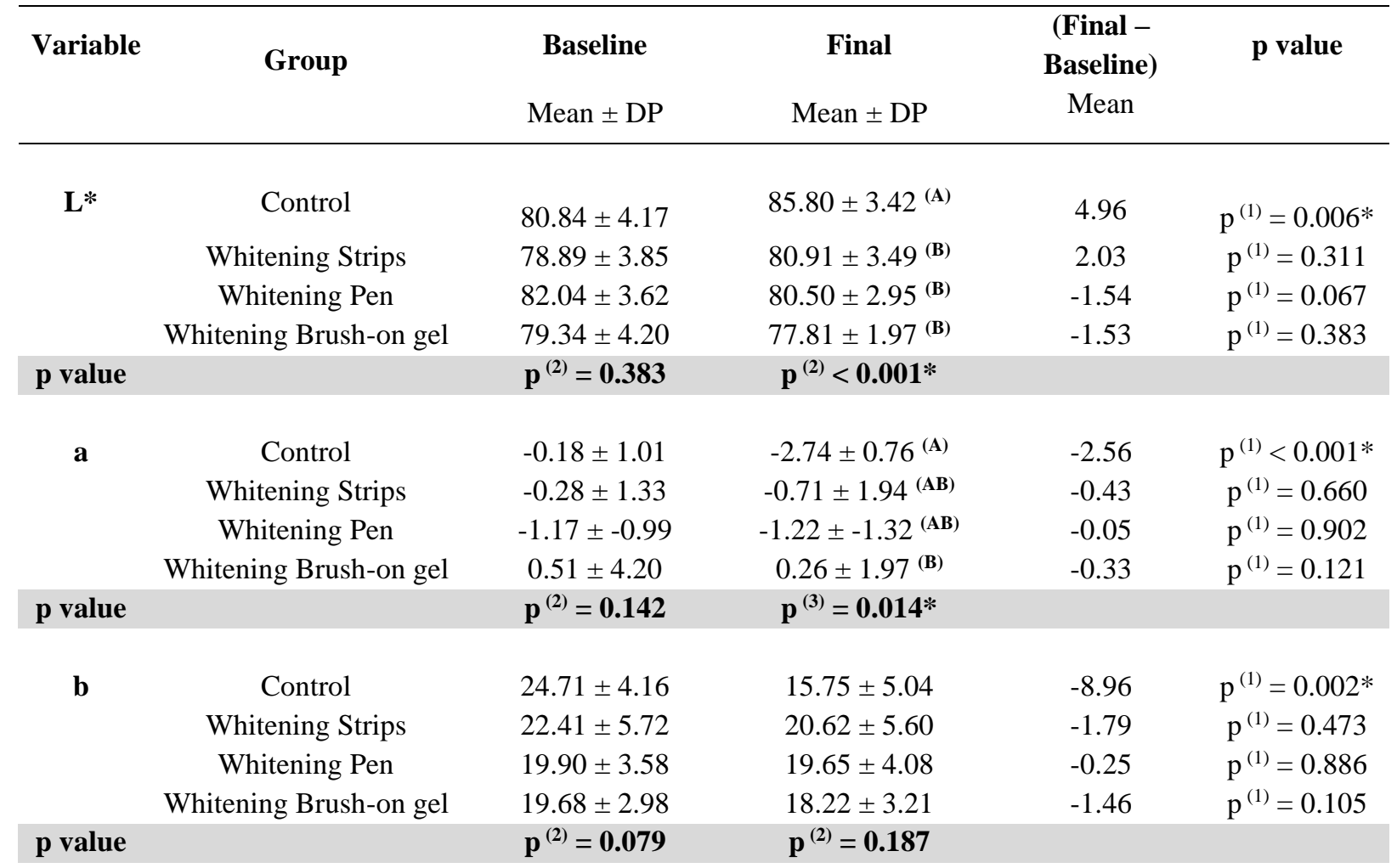

(1) Through the t student test

(2) Through the F test (ANOVA) with Tukey comparisons

(3) Through the F test (ANOVA) with Tamanhe comparisons.

Source: Authors. 
Table 2 - Statistics for $\Delta \mathrm{E} 1$ and $\Delta \mathrm{E} 2$ according to group and assessment.

\begin{tabular}{|c|c|c|}
\hline GROUP & $\begin{array}{c}\Delta \mathbf{E} 1 \\
\text { Mean } \pm \text { DP }\end{array}$ & $\begin{array}{c}\Delta \mathbf{E 2} \\
M e a n+D P\end{array}$ \\
\hline Control & $9.91 \pm 3.20^{(\mathbf{A})}$ & $11.65 \pm 3.46^{(\mathrm{A})}$ \\
\hline Whitening Strips & $6.19 \pm 1.47$ & $8.32 \pm 2.94^{(\mathbf{A B})}$ \\
\hline Whitening Pen & $5.92 \pm 3.47^{(\mathbf{B})}$ & $4.38 \pm 2.98^{(\mathbf{B})}$ \\
\hline Whitening Brush-on gel & $4.20 \pm 2.95^{(\mathbf{B})}$ & $4.83 \pm 2.32^{(\mathbf{B})}$ \\
\hline p value & $\mathbf{p}^{(2)}=0.004 *$ & $\mathrm{p}^{(2)}<0.001 *$ \\
\hline
\end{tabular}

(2) Through the F test (ANOVA) with Tukey comparisons

Note: If the capital letters in parentheses are all distinct, understand the difference between the corresponding groups.

Source: Authors.

Regarding tooth sensitivity, it was only reported by two patients from G1 and two from G4. There were no significant differences ( $p>0.05)$ between groups in relation to this variable.

Of the total of 32 patients undergoing treatment, five (15.6\%) had some type of gingival alteration, these belonging to groups of domestic dental bleaching systems. Only in the positive control group, no gingival changes were observed during treatment.

The degree of satisfaction was higher for G1. The lower degree of satisfaction was found for G2 and G3. Statistically significant difference was found between the groups, as shown in Table 3.

Table 3 - Evaluation of pacients satisfaction with the treatment according to the group.

\begin{tabular}{|c|c|c|c|c|c|c|c|c|c|c|}
\hline \multirow[t]{2}{*}{ GROUP } & \multicolumn{2}{|c|}{ Very satisfied } & \multicolumn{2}{|c|}{ Satisfied } & \multicolumn{2}{|c|}{ Indifferent } & \multicolumn{2}{|c|}{ Insatisfied } & \multirow{2}{*}{$\begin{array}{l}\text { Total } \\
\mathrm{n}\end{array}$} & \multirow[t]{2}{*}{ p value } \\
\hline & $\mathrm{n}$ & $\%$ & $\mathrm{n}$ & $\%$ & $\mathrm{~N}$ & $\%$ & $\mathrm{n}$ & $\%$ & & \\
\hline Control & 3 & 37.5 & 5 & 62.5 & - & - & - & - & 8 & \\
\hline Whitening Strips & 3 & 37.5 & 4 & 50.0 & - & - & 1 & 12.5 & 8 & $\mathrm{p}^{(1)}<$ \\
\hline Whitening Pen & - & - & 2 & 25.0 & 6 & 75.0 & - & - & 8 & $0.001 *$ \\
\hline Whitening Brush & - & - & 1 & 12.5 & 5 & 62.5 & 2 & 25.0 & 8 & \\
\hline
\end{tabular}

(1) Through Fisher's exact test. Source: Authors.

\section{Discussion}

Regarding the age, this study sample was composed by adults and younger adults, which avoided possible interference due to the physiological changes in dental tissues due to age and sclerotic dentin deposition (Selvamani et al., 2013). In addition, discrete age variation contributed to a good sample standardization.

At-home dental bleaching technique is performed with customized trays as a delivery system for bleaching. This whitening approach is safe, more economical and presents a better risk-benefit ratio (Kihn et al., 2000; Auschill et al., 2005; Braun; Jepsen; Krause, 2007). The use of individualized trays allows the peroxide to remain on the dental surface without the interference of saliva. According to the findings of the present study, there is a tendency for a greater bleaching effect for G1 and G4, as shown in Table 2. However, in groups G2 and G3, ineffective results were observed, reaffirming the suggestion of enhancing bleaching therapy when associated with a retainer device.

Adverse effects of bleaching products on enamel may depend on the type of bleaching agent, hydrogen peroxide concentration, and bleaching therapy duration (Meireles et al., 2014; Al-Salehi; Wood; Hatton, 2007). The application of 10\% carbamide peroxide gel increases porosity, depression, and erosion on the dental surface, in addition to decreasing the enamel tension forces (Oliveira; Paes Leme; Giannini, 2005). A few studies demonstrate that the microhardness value of the post- 
bleached enamel generally does not change (Fatima; Ali Abidi; Meo, 2016; Mushashe et al., 2018; Zanolla et al., 2017). When present, the reduction in microhardness can be reversed in up to three months by the remineralization potential of saliva (Leandro et al., 2008).

Regarding the properties related to enamel adhesion strength, fracture, and abrasion resistance after tooth bleaching, it was found that there are few studies on this reference, which generates insufficient data to reach concrete and reliable conclusions (Klarić et al., 2013; Lima Neto et al., 2018). The action of hydrogen peroxide present in Groups 2 and 3 would be physically altering the dental structure, leaving the enamel more porous and susceptible to pigmentation, to the detriment of an effective whitening action. This hypothesis is reinforced by the fact that tooth shade in these two groups revealed a darker posttreatment pattern (Table 1).

One of the most common adverse effects reported during whitening treatment is tooth sensitivity (Rezende et al., 2016). This adverse effect can be explained by the low molecular weight of hydrogen peroxide and free passage of the whitening gel through the enamel and dentin, which can reach the pulp, as well as the increase in the enamel permeability during the whitening treatment (Klarić et al., 2013). As observed in the control group, which presented sensitivity during treatment, the longer contact time of the bleaching gel with the dental structure may have been fundamental to cause tooth sensitivity. On soft tissues, gingival irritation is perceived more frequently, which can be caused by both the whitening substance and the plastic tray used in at-home bleaching (Demarco; Meireles; Masotti, 2009).

Luminosity is the most important factor in determining color, which confirms the statement that low values or bright colors are considered darker (Sikri, 2010). The value of $\mathrm{L} *$ in the present study suffered significant variations in the Control Group (G1) and Whitening strips (G4). After the bleaching treatment, there was an increase in this value indicating a gain in luminosity, however, for G2 and G3, a decrease in the value of $\mathrm{L} *$ was observed, presenting a negative average between the final and initial evaluation, which confirms a lower luminosity for these groups.

Previous studies indicate a similar bleaching effect between whitening strips and at-home whitening with $10 \%$ carbamide peroxide (Cordeiro et al., 2019; Eachempati et al., 2018), this data corroborates the findings of the present study, although this alternative domestic bleaching method has some limitations, such as possible contact of hydrogen peroxide with the oral mucosa, lack of frequency and time of use control (Carey, 2014.; Serraglio et al., 2016).

In terms of gingival irritation, $15.6 \%$ of the patients had some type of gingival alteration, this result was obtained only in groups of over-the-counter products (G2, G3 and G4), the control group (G1) did not present any gingival changes during treatment. The results obtained in this study reaffirm the importance of dentist monitoring during bleaching therapy to avoid adverse effects such as gingival irritation. Several clinical studies showed similar results (Pinto et al., 2017; Carlos et al., 2016; da Costa et al., 2012; Auschill et al., 2012; Auschill et al., 2005), although a few studies showed controversial results (Cordeiro et al., 2019).

The esthetic appearance influences social life, work environment, and other social aspects (Afroz et al., 2013). Changes in the color of the teeth are easily noticed, causing enormous dissatisfaction to the patient. In the present study, the satisfaction degree revealed difference between the groups. According to the statistical analysis employed, the control group (G1) obtained a higher value of satisfaction degree while G2 and G3 achieving a lower degree of satisfaction. It is believed that positive results of bleaching effectiveness obtained in control group (G1) can explain these results.

The interaction of hydrogen peroxide with the dental structure and soft tissues should not be underestimated. The occurrence of trans and postoperative tooth sensitivity, cytotoxic potential, and the promotion of carcinogenesis reinforce the need for attention to safety measures when using this substance (Del Real Garcia et al., 2019; Colares et al., 2019). Studies in cell cultures and animal models reinforce this fact, since there is strong evidence related to genetic damage and, consequently, to the copromotion of carcinogenesis (Vilhena et al., 2019.; Mushashe et al., 2018.; Naik; Tredwin; Scully, 2006). 
Professional follow-up of the treatment is essential to avoid unwanted effects during the whitening treatment, prioritizing the patient's health and its final objective. Thus, bleaching efficacy is greater while maintaining its integrity (Vilhena et al., 2019).

\section{Conclusions}

According to the methodology used in the present study, it is concluded:

1. Among the domestic bleaching strategies evaluated, only the bleaching tapes had a bleaching effect similar to athome bleaching.

2. It was not possible to observe the presence of significant gingival changes for any of the groups.

3. There was no difference between groups for sensitivity reports.

4. Patients who used a whitening solution in a brush and pen had a lower degree of satisfaction with the treatment.

\section{References}

Afroz. S., Rathi, S., Rajput, G., \& Rahman, S. A. (2013). Dental Esthetics and Its Impact on Psycho-Social Well-Being and Dental Self Confidence: A Campus Based Survey of North Indian University Students. J Indian Prosthodont Soc, 13(4), 455-460.

Al-Salehi, S., Wood, D., \& Hatton, P. (2007). The effect of $24 \mathrm{~h}$ non-stop hydrogen peroxide concentration on bovine enamel and dentine mineral content and microhardness. J Dent, 35, 845-850.

Auschill, T. M., Hellwig, E., Schmidale, S., Sculean, A., \& Arweiler, N. B. (2005). Efficacy, side-effects and patients' acceptance of different bleaching techniques (OTC, in-office, at-home). Oper Dent, 30 (2), 156-163.

Auschill, T. M., Schneider-Del Savio, T., Hellwig, E., \& Arweiler, N. B. (2012). Randomized clinical trial of the efficacy, tolerability, and long-term color stability of two bleaching techniques: 18-month follow-up. Quintessence Int, 43 (8), 683-694.

Braun, A., Jepsen, S., \& Krause, F. (2007). Spectrophotometric and visual evaluation of vital tooth bleaching employing different carbamide peroxide concentrations. Dent Mater, 23 (2), 165-169.

Carey, C. M. (2014). Tooth Whitening: What We Now Know. J Evid Based Dent Pract, 14 (Suppl), 70-76.

Carlos, N. R., Bridi, E., Amaral, F. L. B., Franca, F. M. G., Turssi, C. P., Basting, R. T. (2016). Efficacy of home-use bleaching agents delivered in customized or prefilled disposable trays: A randomized clinical trial. Oper Dent, 42 (1), 30-40.

Colares, V. L. P., Lima, S. N. L., Sousa, N. C. F., Araújo, M. C., Pereira, D. M. S., Mendes, S. J. F., Teixeira, S. A., Monteiro, C. A., Bandeca, M. C., Siqueira, W. L., Moffa, E. B., Muscará, M. N., \& Fernandes, E. S. (2019). Hydrogen peroxide-based products alter inflammatory and tissue damage-related proteins in the gingival crevicular fluid of healthy volunteers: a randomized trial. Sci Rep, 9 (1), 3457.

Cordeiro, D., Toda, C., Hanan, S., Arnhold, L. P., Reis, A., Loguercio, A. D., \& Bandeira, M. C. L. (2019). Clinical Evaluation of Different Delivery Methods of At-Home Bleaching Gels Composed of 10\% Hydrogen Peroxide. Oper Dent, 44 (1), 13-23.

da Costa, J. B., McPharlin, R., Hilton, T., Ferracane, J. I., \& Wang, M. (2012). Comparison of two at-home whitening products of similar peroxide concentration and diferente delivery methods. Oper Dent, 37 (4), 333-339.

Demarco, F. F., Meireles, S. S., \& Masotti, A. S. Over-the-counter whitening agents: a concise review. Braz Oral Res. 2009,23 (1):64-70.

Del Real Garcia, J. F., Saldana-Velasco, F. R., Sanchez-de la Rosa, S. V., Ortiz-García, Y. M., Morales-Velazques, G., Gómez-Meda, B. C., Zúñiga-González, G. M., Sánchez-Parada, M. G., \& Zamora-Perez, A. L. (2019). In vivo evaluation of the genotoxicity and oxidative damage in individuals exposed to 10\% hydrogen peroxide whitening strips. Clin Oral Investig, 23 (7), 3033-3046.

Eachempati, P., Kumbargere Nagraj, S., Kiran Kumar Krishanappa, S., Gupta, P., \& Yaylali, I. E. (2018). Home-based chemically-induced whitening (bleaching) of teeth in adults. Cochrane Database Syst Rev, 12 (12), CD006202.

Epple, M., Meyer, F., \& Enax, J. (2019). A Critical Review of Modern Concepts for Teeth Whitening. Dent J (Basel), 7 (3).

Fiorillo, L., Laino, L., De Stefano R., D'Amico C., Bocchieri, S., Amoroso, G., Isola, G., \& Cervino, G. (2019). Dental Whitening Gels: Strengths and Weaknesses of an Increasingly Used Method. Gels, 5 (3).

Fatima, N., Ali Abidi, S. Y., \& Meo, A. A. (2016). In vitro comparative study of two different bleaching agents on micro-hardness dental enamel. $J$ Coll Physicians Surg Pak, 26, 83-86.

Huskisson, C. E., Jones, J., \& Scott, P. J. (1976). Aplicação de escalas visual-analógicas à medida da capacidade funcional. Reumatologia, 15 (3), $185-187$.

Kihn, P. W., Barnes, D. M., Romberg, E., \& Peterson, K. (2000). A clinical evaluation of 10 percent vs. 15 percent carbamide peroxide tooth-whitening agents. J Am Dent Assoc, 131 (10), 1478-1484. 
Klarić, E., Marcius, M., Ristić, M., Sever, I., Prskalo, K., \& Tarle, Z. (2013). Surface changes of enamel and dentin after two different bleaching procedures. Acta Clin Croat, 52 (4), 419-429.

Leandro, G. A., Attia, M. L., Cavalli, V., do Rego, M. A., \& Liporoni, P. C. (2008). Effects of 10\% carbamide peroxide treatment and sodium fluoridetherapies on human enamel surface microhardness. Gen Dent, 56, 274-277.

Li, Y., Lee, S. S., Cartwright, S. L., \& Wilson, A. C. (2003). Comparison of clinical efficacy and safety of three professional at-home tooth whitening systems. Compendium of Continuing Education in Dentistry, 24 (5), 357-360.

Lima Neto, C. F., Silva, C. B., Silva, M. A. B., Vitti, R. P., Silva Zanta, C. L. P., \& Tonholo, J. (2018). Tooth whitening affects bond strength of adhesive systems in enamel. Rev Matéria, 23 (4).

Meireles, S. S., Goettems, M. L., Dantas, R. V., Bona, A. D., Santos, I. S., \& Demarco, F. F. (2014). Changes in oral health related quality of life after dental bleaching in a double-blind randomized clinical trial. J Dent, 42, 114-121

Mushashe, A. M., Coelho, B. S., Garcia, P. P., Rechia, B. C. N., da Cunha, L. F., Correr, G. M., \& Gonzaga, C. C. (2018). Effect of different bleaching protocols on whitening efficiency and enamel superficial microhardness. J Clin Exp Dent, 10 (8), e772-775.

Naik, S., Tredwin, C. J., \& Scully, C. (2006). Hydrogen peroxide tooth-whitening (bleaching): review of safety in relation to possible carcinogenesis. Oral Oncol, 42 (7), 668-674.

Oliveira, R. D., Paes Leme, A. F., \& Giannini, M. (2005). Effect of a carbamide peroxide bleaching gel containing calcium or fluoride on human enamel surface microhardness. Braz Dent J, 16 (2), 103-106.

Pinto, M. M., Goncalves, M. L., Mota, A. C., Deana, A. M., Olivan, S. R., Bortoletto, C., Godoy, C. H., Vergilio, K. L., Altavista, O. M., Motta, L. J., \& Bussadori, S. K. (2017). Controlled clinical trial addressing teeth whitening with hydrogen peroxide in adolescents: A 12 -month follow-up. Clinics, 72 (3), 161-170.

Rezende, M., Loguercio, A. D., Kossatz, S., \& Reis, A. (2016). Predictive factors on the efficacy and risk/intensity of tooth sensitivity of dental bleaching: a multi regression and logistic analysis. J Dent, 45, 1-6.

Selvamani, M., Madhushankari, G. S., Basandi, P. S., Donoghue, M., Nayak, V., \& Diwakar, G. (2013). Effect of Vitality on Translucent Dentine - A Study. J Int Oral Health, 5 (2), 1-7.

Serraglio, C. R., Zanella, L., Dalla-Vecchia, K. B., \& Rodrigues-Junior, S. A. (2016). Efficacy and safety of over-the-counter whitening strips as compared to home-whitening with $10 \%$ carbamide peroxide gel--systematic review of RCTs and metanalysis. Clin Oral Investig, 20 (1), 1-14.

Sikri, V. K. (2010). Color: Implications in dentistry. J Conserv Dent, 13 (4), 249-55.

Vilhena, K. F. B., Nogueira, B. C. L., Fagundes, N. C. F., Loretto, S. C., Angelica, R. S., Lima, R. R., \& Souza Júnior, M. H. S. (2019). Dental enamel bleached for a prolonged and excessive time: Morphological changes. Plos One, 14 (4), e0214948.

Wang, Y., Wen, X., Jia. Y., Huang, M., Wang, F., Zhang, X., Bai, Y., Yuan, G., \& Wang, Y. (2020). Piezo-catalysis for nondestructive tooth whitening. Nat Commun, 11 .

Zanolla, J., Marques, A., da Costa, D. C., de Souza, A. S., \& Coutinho, M. (2017). Influence of tooth bleaching on dental enamel microhardness: a systematic review and meta-analysis. Aust Dent J, 62 (3), 276-282. 